\title{
Perancangan Sistem Informasi Manajemen Data Kepegawaian Berbasis Web Pada Baper Chips Indonesia
}

\author{
Designing Of Personel Data Management Information System Based On Web At Baper Chips \\ Indonesian \\ Hesti Rauni ${ }^{l}$,Rika Rosnelly ${ }^{2 *}$ \\ ${ }^{1}$ Jurusan Teknik Informatika, Fakultas Teknik dan Ilmu Komputer \\ ${ }^{2}$ Dosen Jurusan Ilmu Komputer, Universitas Potensi Utama \\ ${ }^{1,2}$ Universitas Potensi Utama, K.L. Yos Sudarso KM 6,5 No. 3A Tj. Mulia - Medan \\ Email:hestieraunie@gmail.com ${ }^{1}$,rikarosnelly@gmail.com ${ }^{2}$ \\ *Corresponding author
}

\begin{abstract}
ABSTRAK
Baper Chips Indonesia adalah salah satu Usaha Mikro Kecil Menengah (UMKM) yang ada di Indonesia. Baper Chips bergerak dibidang kuliner yang memproduksi keripik tradisional seperti keripik singkong dan keripik pisang. Ditahun 2016 hingga saat ini Baper Chips berkembang menjadi produsen keripik brownies yang memproduksi brownies panggang dengan tiga varian rasa. Pertumbuhan bisnis Baper Chips yang semakin meningkat itu tidak lepas dari peran setiap orang yang berada didalamnya, dengan kata lain "orang" merupakan salah satu kunci keberhasilan pertumbuhan organisasi. Sistem Informasi Manajemen Kepegawaian merupakan suatu sistem informasi manajemen yang berfungsi untuk mengelola data, manajemen dan administrasi kepegawaian sebuah instansi, perguruan tinggi ataupun perusahaaan. Sistem Informasi Manajemen Kepegawaian menjadi solusi tepat bagi sebuah instansi, perusahaaan ataupun perguruan tinggi dalam mengatasi masalah manajemen kepegawaian.Salah satu dasar atau referensi penting dalam penetapan sebuah kebijakan di bidang kepegawaian adalah data pegawai, berupa data individu masing-masing pegawai lengkap dengan riwayatnya. Sistem ini berbasis website yang menggunakan bahasa pemrograman PHP dan database MySQL.
\end{abstract}

Kata Kunci: Baper Chips Indonesia Sistem Informasi Manajemen Data Kepegawaian, PHP dan MySQL.

\section{ABSTRACT}

Baper Chips Indonesia is one of the micro, Small and medium enterprises (UMKM) in indonesian. Baper Chips is engaged in a culinary field that produces traditional chips such as cassava chips and banana chips. In 2016 until now, Baper chips have developed into a producer of baked brownies chips with three flavors. The increasing Baper chips business growth cannot be separated from the role of everyone in it, in other words "people" is one of the keys to the success of organizational growth. Personnel management infotmation system is a management information system that functions to manage data, management and personnel administration of an agency, college or company. Personnel management information system is the right solution for an agency, company o $r$ college in overcoming personnel management problems. The basis or important reference in basic or important reference in determining a policy in the field of employment is employee data, in the form of individual data for each employee complete with their history. This system is based on a website that uses the PHP website that uses the PHP programming language and MySQL database.

Keywords :Baper Chips Indonesian,Staffing data kepegawaian information system, PHP and $M y S Q L$ 


\section{PENDAHULUAN}

Baper Chips Indonesia adalah salah satu Usaha Mikro Kecil Menengah (UMKM) yang ada di Indonesia. Baper Chips bergerak dibidang kuliner yang memproduksi keripik tradisional seperti keripik singkong dan keripik pisang. Ditahun2016 hingga saat ini Baper Chips berkembang menjadiprodusen keripik brownies yang memproduksi brownies panggang dengan tiga varian rasa[1].

Pertumbuhan bisnis Baper Chips yang semakin meningkat itutidaklepasdari peran setiap orang yang berada didalamnya, dengan kata lain"orang" merupakan salah satu kunci keberhasilan pertumbuhan organisasi. Jumlah pegawaiyang bekerja di Baper Chips mencapai16 orang pegawai harian,yang terdiri dari pegawai tetap, cassual dan OJT (OnJobTraining) dan 123 orang sebagai resellertersebardi 24 Kota di Indonesia.Untuksaat iniBaper Chips belum memanfaatkan teknologi untuk mengelola data seluruh pegawai tetap, perusahaan hanya menyimpan data pegawai menggunakan arsip yang dibedakan berdasarkan departemen masing-masing[2].

Berdasarkan sistem informasi yang berjalan saat ini,seringkali perubahan -perubahan yang terjadi tidak segera diketahui administrasi. Penyimpanan data kepegawaian masih dalam berbentuk arsip, sehingga membutuhkan ketelitian tinggi dan memakan waktu yang cukup lama untuk mencari data kepegawaian yang diinginkan serta dapat menyebabkan hilangnya arsip yang telah disimpan. Akibatnya dalam hal data pokok atau data induk sekalipun, bisa perlu waktu lama untuk menemukannya, bahkan memungkinkan terjadi kesalahan.Oleh karena itu,untuk memaksimalkan pengelolaan data pegawai secara keseluruhan, dibutuhkan system informasi manajemen data kepegawaian berbasis web yang mampu mengelola datapegawai, baik itu pegawai tetap, pegawai kontrak maupun OJT dan reseller[3].

Dengan adanya sistem ini diharapkan mampu mengelola basis data kepegawaian dengan teratur dan terorganisir dan nantinya akan diimplementasikan ke seluruh departemen[4].

SDLC (System Development Life Cycle) atau sering disingkat dengan SDLC merupakan pengembangan yang berfungsi sebagai sebuah mekanisme untuk mengidentifikasikan perangkat lunak[5].

Penelitian yang telah dilakukan oleh Hilman 2017, tentang melakukan penelitian yaitu "Sistem Informasi Manajemen Kepegawaian di Dinas Komunikasi dan Informatika Bandung Barat". Penelitian yang telah dilakukan oleh Muhdar 2018, tentang melakukan penelitian yaitu "Sistem Informasi Data Pegawai Berbasis Web pada Kementerian Kelautan dan Perikanan Kota Ternate". Penelitian yang telah dilakukan oleh Andi 2015, tentang melakukan penelitian yaitu" Sistem informasi manajemen kepegawaian departemen investasi power (DIPw) PT. Wijaya Karya (Persero) Tbk". Penelitian yang telah dilakukan oleh Athin 2018, tentang melakukan penelitian yaitu "Implementasi Sistem Informasi Manajemen Kepegawaian (Simpeg) Sebagai Dasar Pengambilan Keputusan Bidang Sumber Daya Manusia (SDM) di Bkdiklatda Kota Salatiga". Penelitian yang telah dilakukan oleh Siti 2019, tentang melakukan penelitian yaitu "Rancang Bangun Ssitem Informasi Kepegawaian (Simpeg) Dengan SDLC Metode Waterfall Studi Kasus di Kantor BKPLD Kabupaten Tasikmalaya". Penelitian yang telah dilakukan oleh Riana 2019, tentang melakukan penelitian yaitu "Dukungan Sistem Informasi Manajemen Kepegawaian Terhadap Pengambilan Keputusan di Bkpp Kabupaten Sukoharjo". Penelitian yang telah dilakukan oleh Sugiarto 2014, tentang melakukan penelitian yaitu " Perancangan Dan Implementasi Lampu Jalan Otomatis Dengan Menggunakan Solar Cell Berbasis ATMEGA 8535 ”. Penelitian yang telah dilakukan oleh Safrizal 2020, tentang melakukan penelitian yaitu"Penerapan Aplikasi SiCerdas Berbasis Web Pada Siswa Raudhatul Athfal (RA) Nurul Hasanah". Penelitian yang telah dilakukan oleh, tentang melakukan penelitian yaitu"Sistem Kasus penelitian ini hampir sama dengan penelitian yang akan peneliti kembangkan yaitu tentang pembuatan program pengetahuan tentang perancangan sistem informasi manajemen data kepegawaian berbasis web[6].

Dari ke kedelapan penelitian diatas sangat mendukung peneliti untuk mengembangkan penelitian tentang keamanan data kepegawaian dengan berbasis web, namun terdapat perbedaan dari segi metode yang diangkat menjadi topik penelitian, peneliti merancang aplikasi ini berbasis web dengan menggunakan bahasa program PHP. 


\section{METODE PENELITIAN}

2.1. Metode Pengumpulan Data

Sistem yang dirancang tentunya memerelukan pengumpulan data, dalam proses pengumpulan data terdapat beberapa cara,yaitu :

a. Pengamatan (Observation), yaitu pengumpulan data dan informasi yang dilakukan dengan cara pengamatan langsung ke Baper Chips Indonesia.

b. Wawancara (interview), yaitu pengumpulan data dengan cara melakukan tanya jawab dengan pemilik Baper Chips Indonesia.

c. Penelitian Perpustakaan (Library Research), yaitu melakukan studi pustaka untuk datadata yang berhubungan dengan penelitian.

2.2. Prosedur Perancangan

Langkah-langkah yang diperlukan untuk mencapai tujuan perancangan dapat dilihat pada gambar di bawah ini :

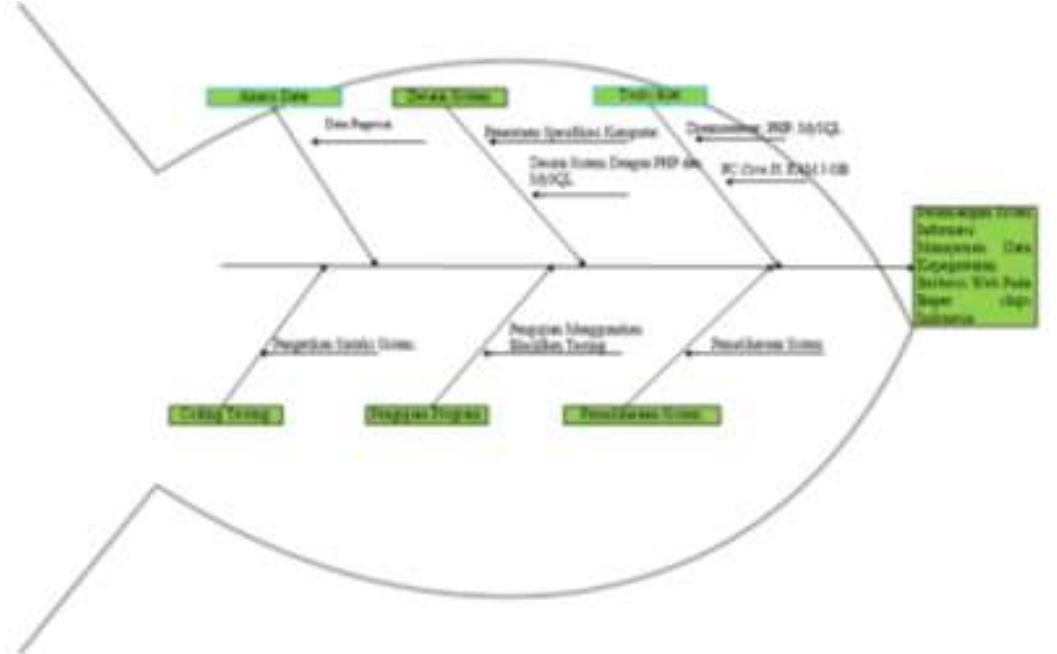

Gambar 1. Diagram Fishbone

1. Akuisi Data

Akuisi Data adalah menganalisa kebutuhan sistem yang sudah ada dan menambahkan sistem yang baru dalam perancangan bila ternyata dibutuhkan. Sesuai penyelesaian yang akan dilakukan, kebutuhan pokok yang harus ada pada perancangan aplikasi ini adalah:

a. Aplikasi ini membutuhkan data pegawai yang dapat digunakan sebagai inputan pada saat pengolahan data pegawai pada Baper Chips Indonesia.

b. Aplikasi ini membutuhkan hardware minimum laptop Processor Core I3, RAM 3 GB dan HDD 500. Membutuhkan software Sistem Operasi Windows, Sistem Aplikasi Dreamweaver, Localhost dan MySQL.

2. Desain Sistem

Desain sistem adalah proses menerjemahkan syarat kebutuhan sebuah perancangan perangkat lunak yang dapat diperkirakan sebelum dibuat kode program. Tahapan desain yang akan dilakukan dalam pembuatan sistem dan aplikasi yang akan dirancang adalah:

a. Mendesain sistem dengan menggunakan UML (Unified Modeling Language).

b. Menggunakan aplikasi dreamwere untuk mendesain aplikasi.

c. Menggunakan aplikasi visio untuk menggambarkan Flowchart sistem.

3. Tools/Alat

Tools/Alat merupakan perangkat yang digunakan untuk membantu menyelesaikan pekerjaan seseorang berdasarkan pekerjaan dan fungsi dari masing-masing pekerjaan tersebut.

4. Coding Testing 
Coding merupakan penerjemahan desain dalam bahasa yang bisa dikenali oleh komputer. Dilakukan oleh programmer yang akan menterjemahkan transaksi yang diminta oleh user. Tahapan inilah yang merupakan tahapan secara nyata dalam mengerjakan suatu sistem. Dalam artian penggunaan komputer akan dimaksimalkan dalam tahapan ini. Setelah pengkodean selesai maka akan dilakukan testing terhadap sistem yang telah dibuat tadi. Tujuan testing adalah menemukan kesalahan-kesalahan terhadap system tersebut dan kemudian bisa diperbaiki.

5. Pengujian Program

Pada tahapan pengujian sistem maka dilakukan pengujian secara Black-Box, yang meliputi pengujian fungsional dan ketahanan sistem. Dari hasil pengujian sistem inilah dapat diketahui kesesuaian hasil perancangan dengan analisis kebutuhan yang diharapkan.

6. Pemeliharaan Sistem

Pada pemeliharaan sistem yang perlu dilakukan untuk menjaga semua data-data yang telah tersimpan kedalam aplikasi agar tidak hilang atau terinfeksi virus adalah sebagai berikut:

a. Melakukan perawatan terhadap komponen-komponen hardware dan software.

b. Menggunakan program anti virus agar data maupun file tidak terinfeksi atau dirusak oleh virus.

c. Menerapkan pemeliharaan sistem aplikasi dengan melakukan proses update pada database

Jadi penerapan prosedur perancangan untuk perusahaan tersebut yaitu dimana proses nya hanya di model perancangan dengan memenuhi ada Akuisi data, Desain sistem, Tools/Alat, Coding Testing, Pengujian program, dan Pemeliharaan sistem. Dengan ke enam penerapan tersebut sistem berjalan seperti itu. Tidak ada menggunakan perhitungan dalam prosedur tersebut.

\section{HASIL PEMBAHASAN}

\subsection{Use Case Diagram}

Dalam penyusunan suatu program diperlukansuatu model data yang berbentuk diagram yang dapat menjelaskan suatu alur proses sistem yang akan di bangun. Dalam penelitian ini penulis menggunakan metode UML yang dalam metode itu penulis menerapkan diagram use case. Maka di gambarlah suatu bentuk diagram use case yang dapat dilihat pada Gambar 2.

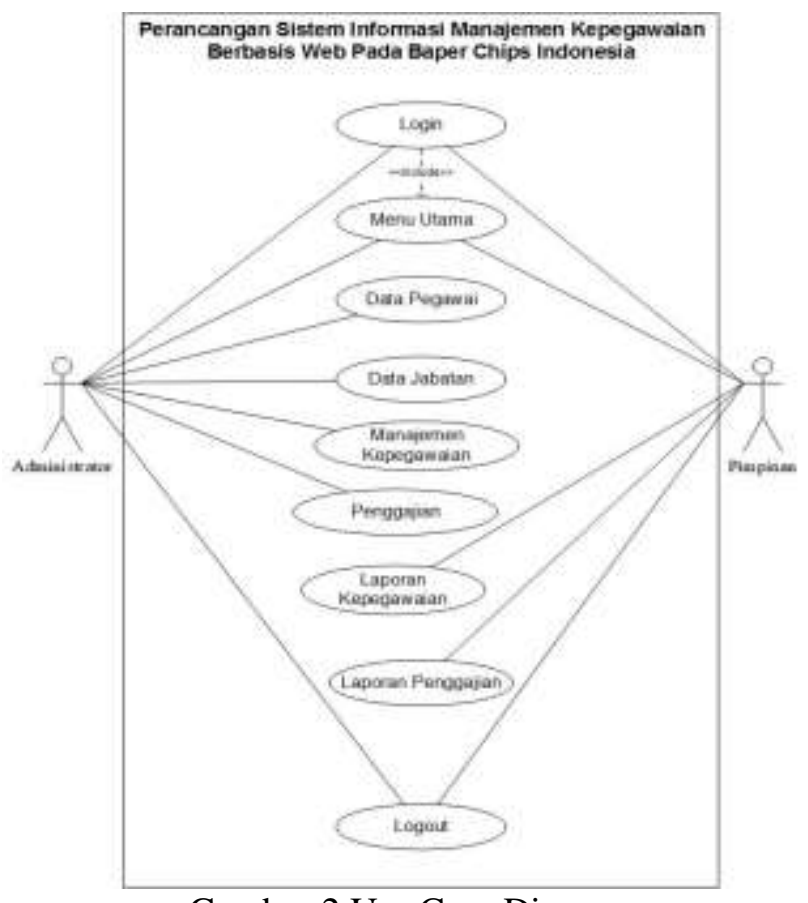

Gambar 2.Use Case Diagram 


\subsection{Class Diagram}

Class adalah sebuah spesifikasi yang jika diinstansiasi akan menghasilkan sebuah objek dan merupakan inti dari pengembangan dan desain berorientasi objek. Class menggambarkan keadaan (atribut/properti) suatu sistem, sekaligus menawarkan layanan untuk memanipulasi keadaan tersebut (metoda/fungsi), seperti Gambar 3

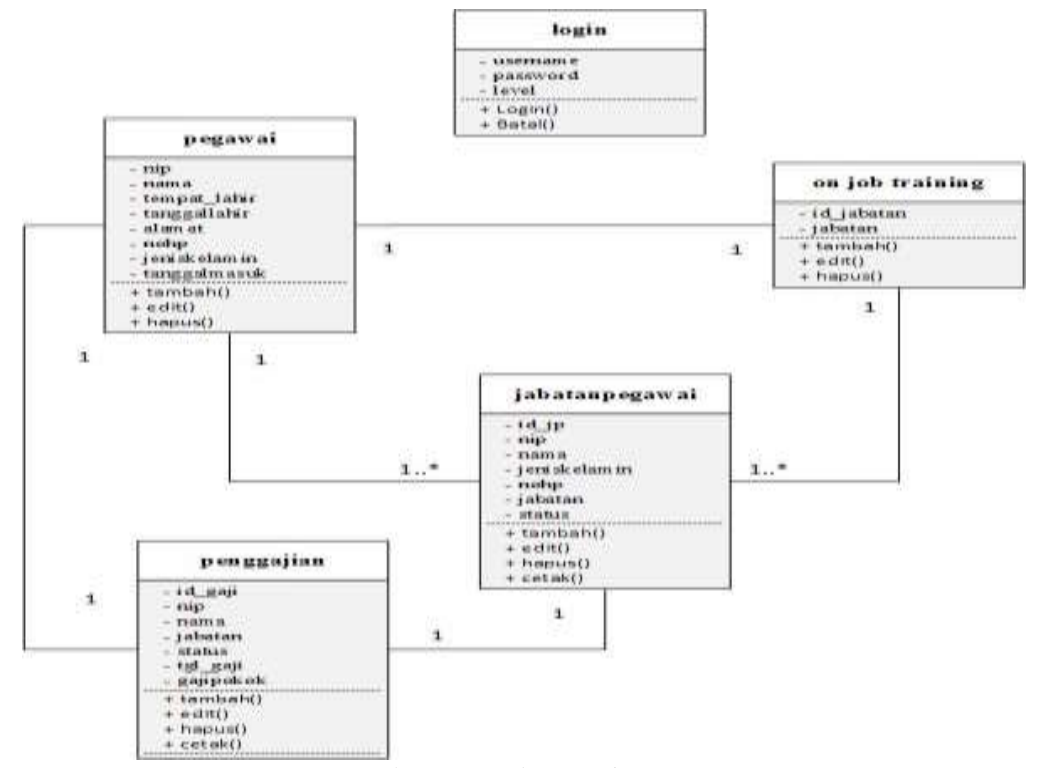

Gambar 3. Class Diagram

\subsection{Activity Diagram}

1. Activity Diagram Login

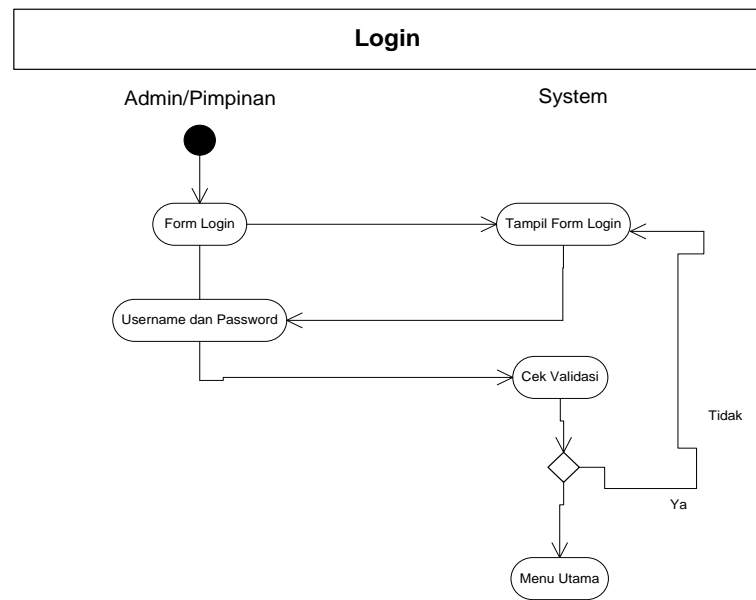

Gambar 4. Activity Diagram Login

2. Activity Diagram Input Data Pegawai

Activity Diagram Input Data Pegawai menggambarkan aktivitas untuk melakukan pengolahan data pegawai. Dimana administrator dapat melakukan edit, hapus dan cetak laporan. Adapun bentuk activity diagram Input Data Pegawai dapat ditunjuk kan pada Gambar 5. 


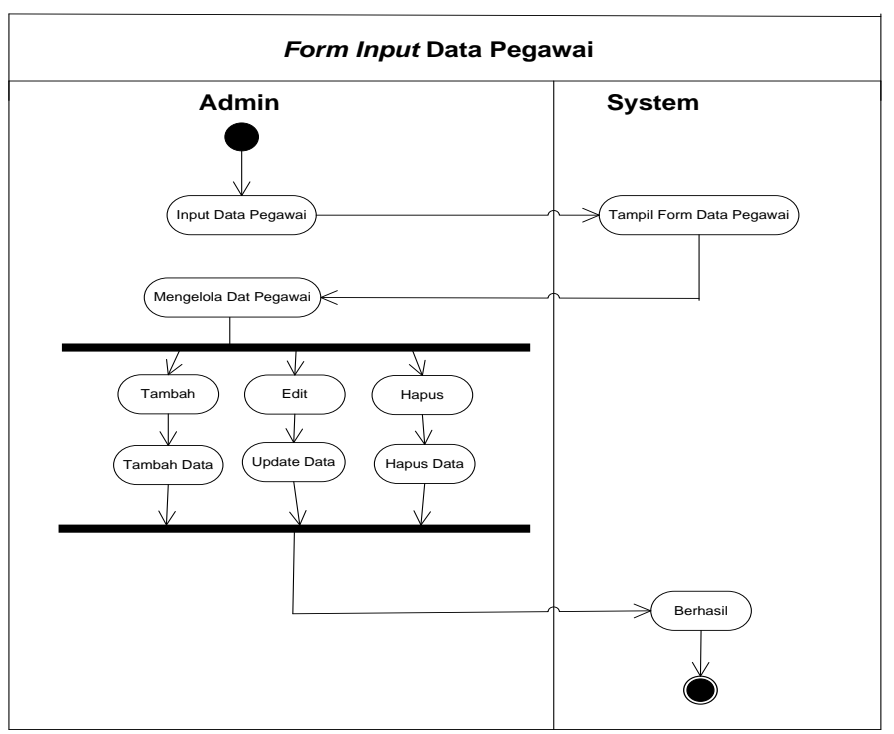

Gambar 5 Activity Diagram Input Data Pegawai

\subsection{Sequence Diagram}

Sequence Diagram menggambarkan kegiatan pada sebuah skenario, diagram ini menunjukkan sejumlah contoh objek dan message (pesan) yang diletakkan diantara objek-objek ini dalam use case berikut gambar Sequence diagram .

1. Sequence Diagram Login

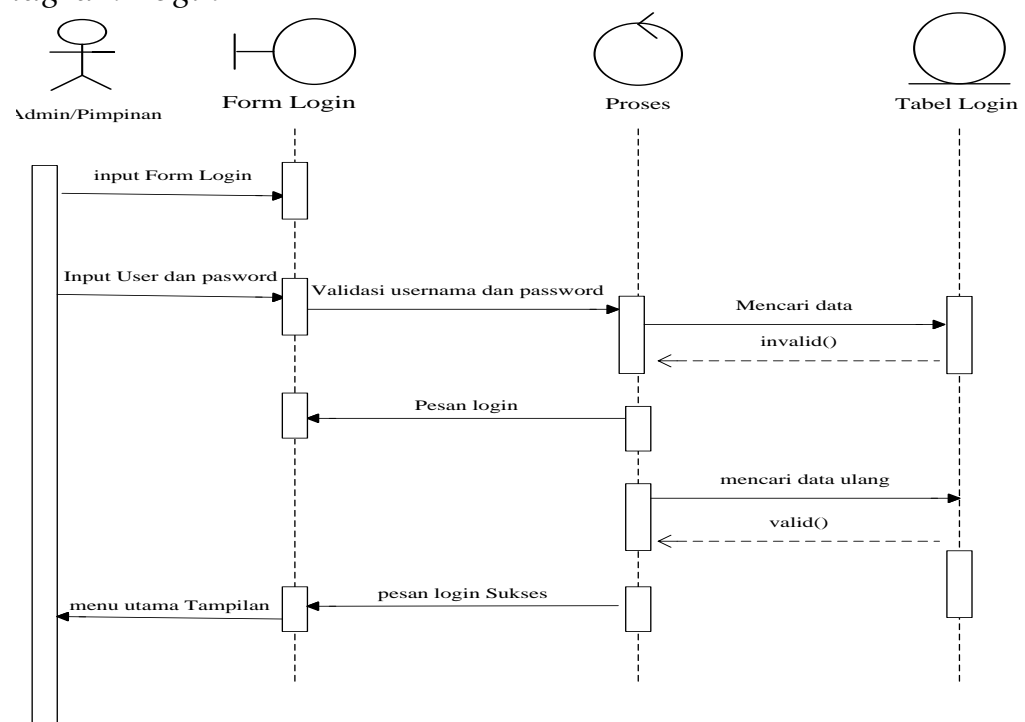

Gambar 6. Sequence Diagram Login

2. Sequence Diagram Data Pegawai 


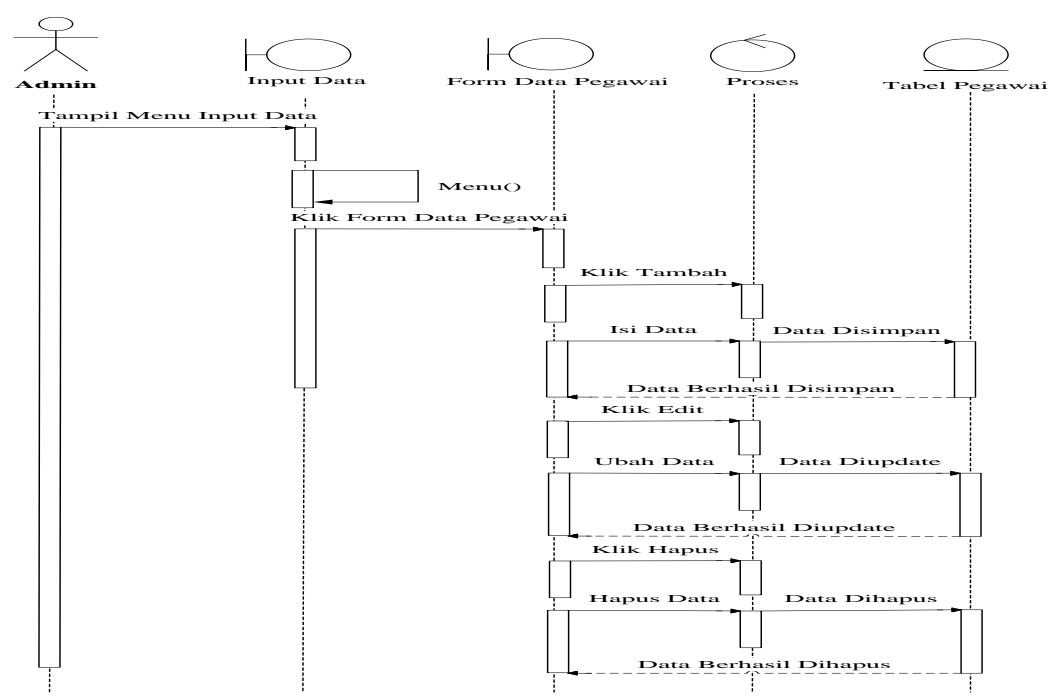

Gambar 7. Sequence Diagram Data Pegawai

3. Sequence Diagram Logout

Sequence Diagram Logout dapat dilihat pada gambar 8 sebagai berikut:

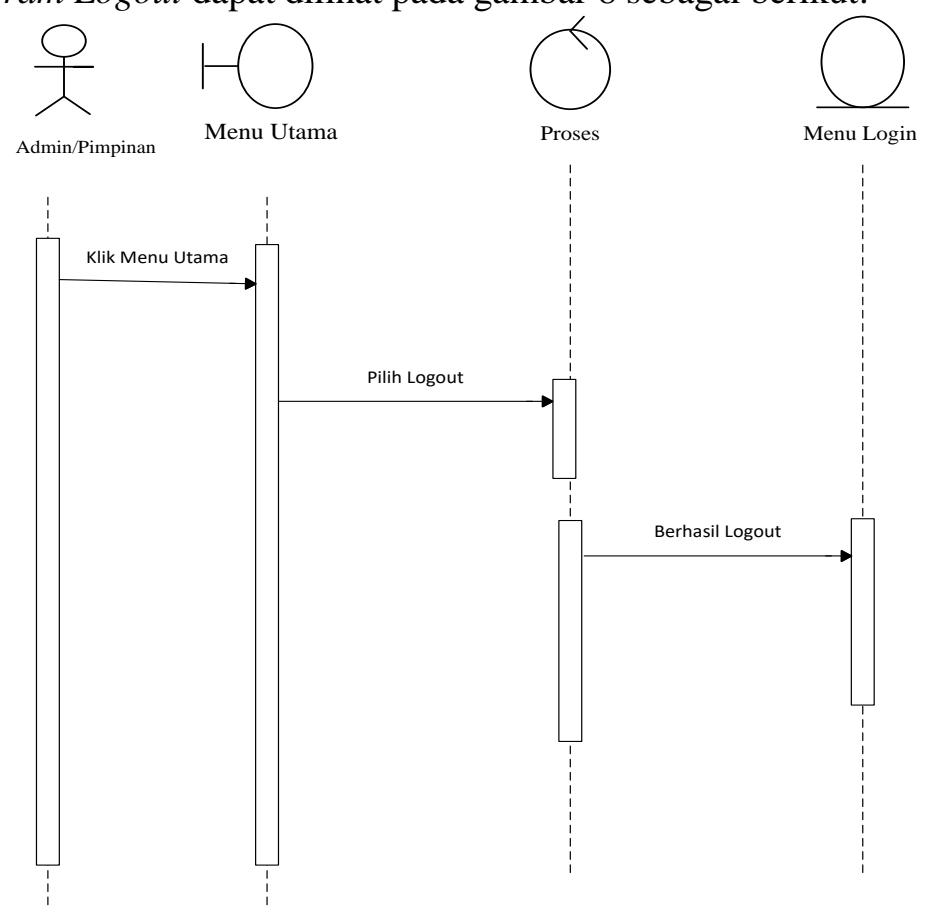

Gambar 8. Sequence Diagram Logout

\subsection{Hasil Tampilan Aplikasi}

A. Tampilan Aplikasi Untuk Admin

1. Halaman Home Admin

Halaman ini merupakan halaman pertama saat admin membuka aplikasi. Dalam halaman ini berisi tampilan utama aplikasi. Seperti pada gambar 9 berikut ini : 


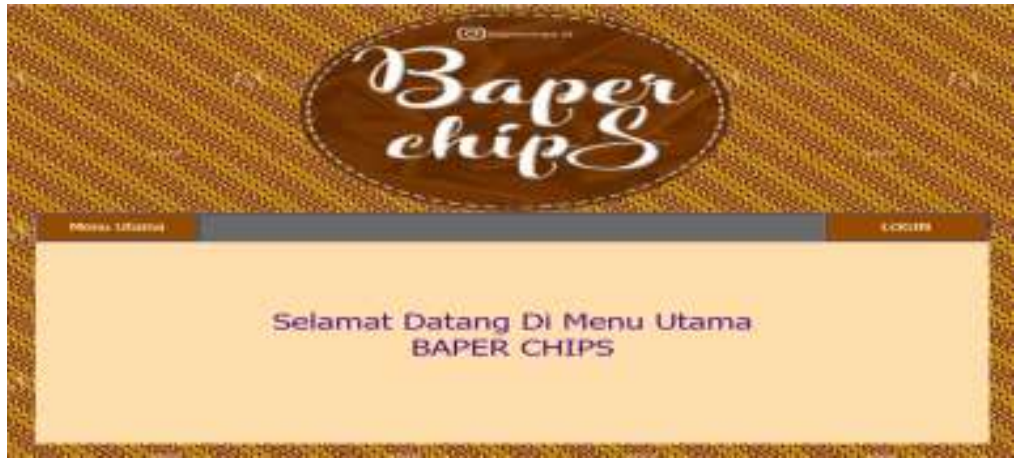

Gambar 9. Halaman Home Admin

\section{Halaman Login Admin}

Halaman ini merupakan halaman login pada saat admin mengklik tombol login di halaman home. Halaman ini berisi username dan password untuk diisi oleh admin pada saat akan mengakses aplikasi.

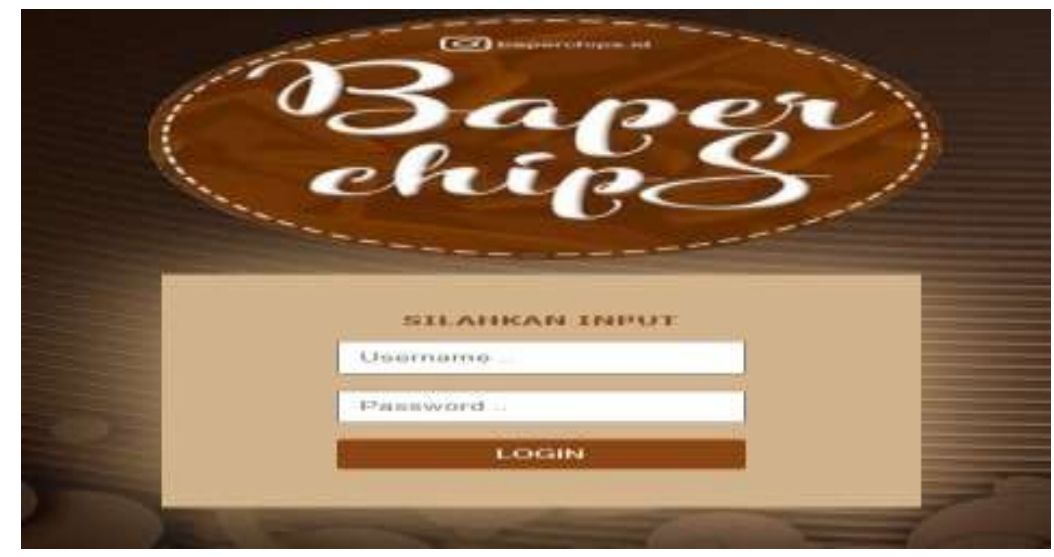

Gambar 10. Halaman Login Admin

3. Halaman Data Pegawai

Halaman ini berisi macam-macam Data Pegawai dar iBaper Chips Indonesia. Padahalaman ini admin bias menambah, mengedit dan menghapus data. Di halaman ini juga terdapat menu-menu dari Baper Chips Indonesia. Dapat dilihat pada Gambar 11 berikut ini:

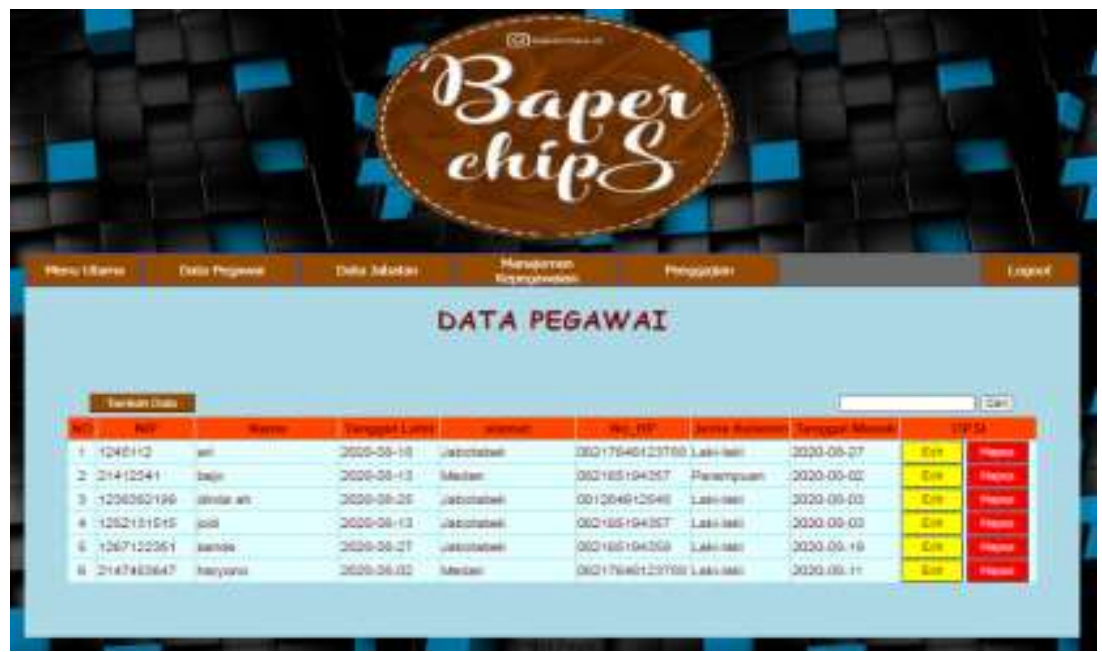

Gambar 11. Halaman Data Pegawai

4. Halaman Tambah Data Pegawai 
Halaman ini merupakan halaman yang menampilkanTambah data dari data Pegawai, d imana halaman ini untuk menambah data pegawai .Dapat dilihat pada Gambar 12 berikut :

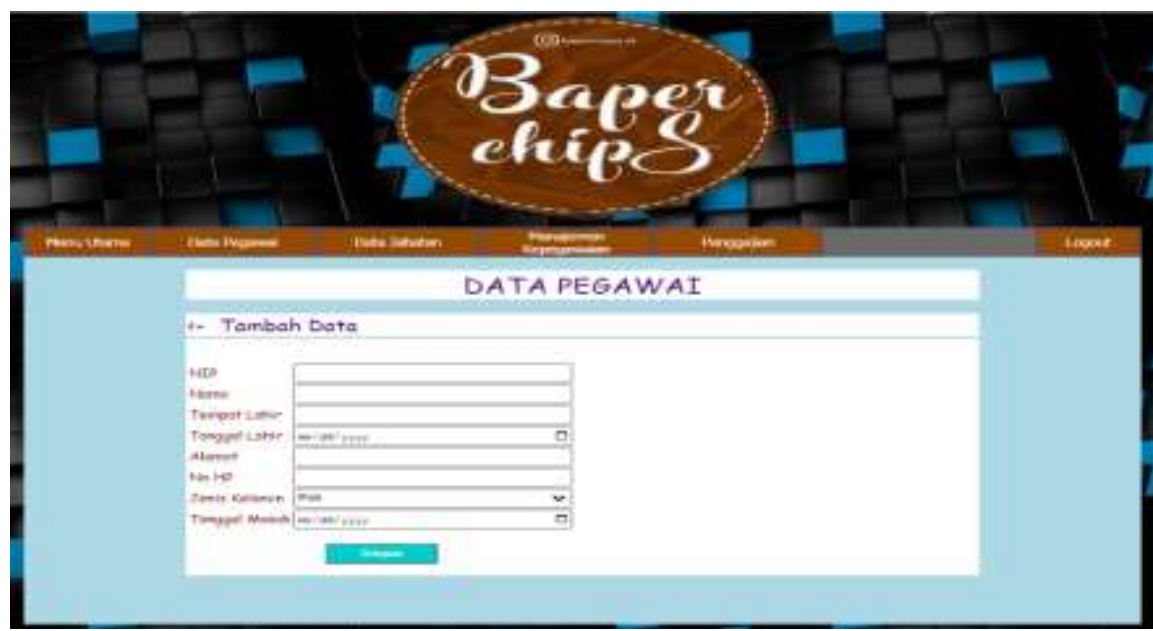

Gambar 12. Halaman Tambah Data Pegawai

5. Halaman Edit Data Pegawai

Halaman ini merupakan halaman yang menampilkan Edit data dari data Pegawai. Halaman ini untuk melakukan perubahan data yang sudah di input awalnya tetapi ada salah data Pegawai. Dapat Dilihat Pada Gambar 12 Berikut Ini:

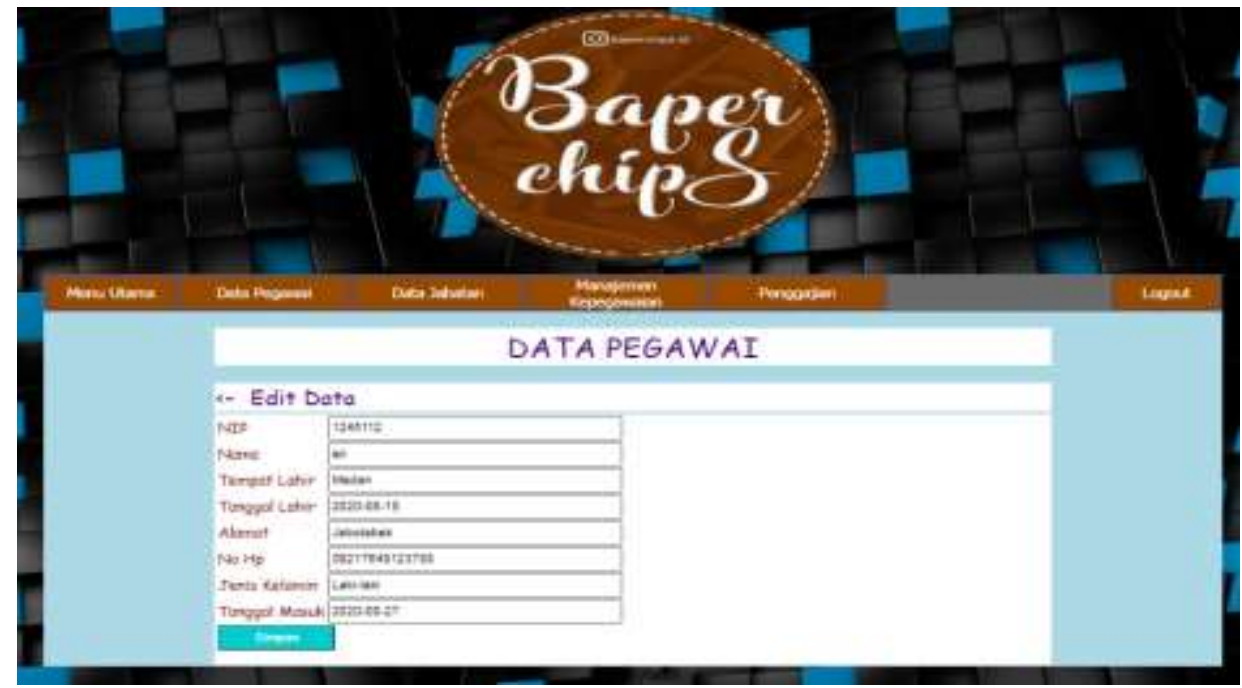

Gambar 13. Halaman Edit Data Pegawai

B. Tampilan Aplikasi Untuk Pimpinan

1. Halaman Menu Utama Pimpinan

Halaman ini merupakan halaman pertama saat pimpinan membuka aplikasi. Dalam halaman ini berisi tampilan utama aplikasi. 


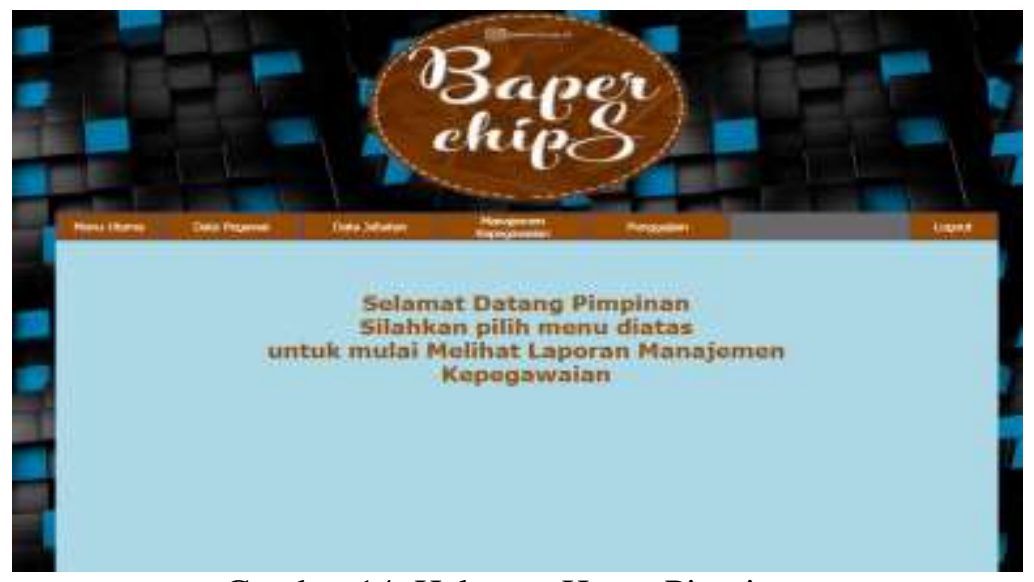

Gambar 14. Halaman Home Pimpinan

2. Halaman Login Pimpinan

Halaman ini merupakan halaman login pada saat pimpinan mengklik tombol login di halaman home. Halaman ini berisi username dan password untuk diisi oleh pimpinan pada saat akan mengakses aplikasi.

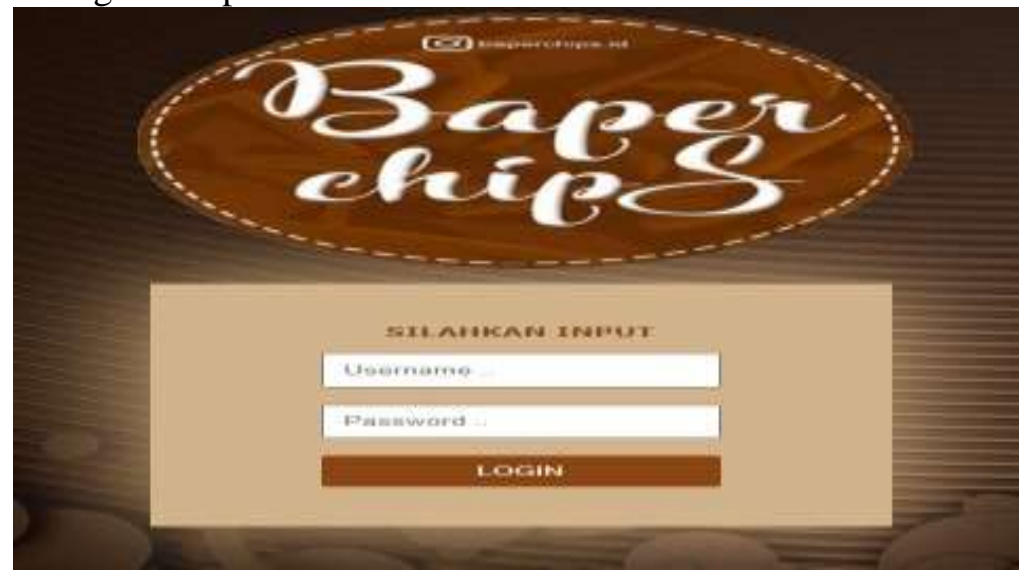

Gambar 15. Halaman Login Pimpinan

3. Halaman Laporan Data Pegawai

Halaman ini berisi kan tampilan Laporan data pegawai. Pada Halaman ini adalah tempat dimana pimpinan cetak laporan data pegawai dan bias menyimpan laporan data pegawai dalam bentuk pdf.

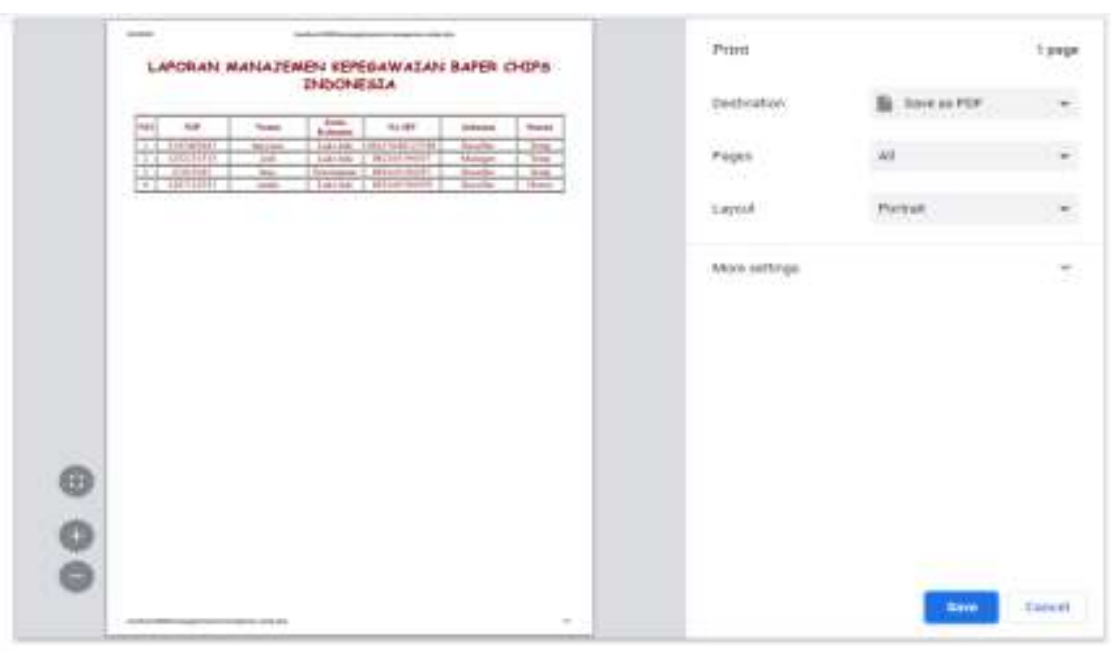

Gambar 16. Halaman Laporan Data Pegawai 
3.6. Kelebihan dan Kekurangan Sistem

Kelebihan sistem ini di antaranya yaitu :

1. Tampilan sistem yang menarik dan mudah ipahami.

2. Tampilan data-data Kepegawaian dapat ditampilkan sesuai dengan kebutuhan pengguna.

3. Tampilan laporan data pegawai yang bias dicetak dalam bentuk pdf.

4. Data-data yang disimpan pada database dapat ditambah, diubah dan dihapus langsung dari aplikasi web oleh admin, tanpa mengubahnya dari database.

Kekurangan sistem ini diantaranya yaitu :

1. Fitur dalam aplikasi masih terbatas, sehingga kedepannya dibutuhkan pengembangan sistem agar lebih menarik, efisien dan efektif.

2. Pimpinan hanya bias melihat data pegawai dan cetak laporan data pegawai yang telah di olah oleh admin Baper Chips Indonesia.

3.

\section{KESIMPULAN}

Berdasarkan penelitian yang telah dilakukan selama membuat aplikasi Sistem Informasi Manajemen Data Kepegawaian pada Baper Chips Indonesia. Sistem yang diterapkan ini berbasis web. Berdasarkan uraian tersebut dapat diambil kesimpulan sebagai berikut:

1. Aplikasi yang dibangun khusus untuk membantu pihak Baper Chips Indonesia dalam proses mengelola data pegawai sehingga pengelolaan data pegawai lebih efektif dan efisien

2. Dengan dibangunnya Sistem Informasi Manajemen Data Kepegawaian Berbasis Web ini sangat membantu, karena memiliki beberapa kelebihannya itu dapat memudahkan dalam penginputan data pegawai, penyimpanan yang aman karena disimpan di database, proses penginputan yang lebih efisien.

3. Aplikasi yang telah dibangun membantu pihak Baper Chips Indonesia untuk mengetahui informasi dalam penyimpanan data pegawai sehingga mempermudah pekerjaan manajemen kepegawaian dengan lebih cepat.

\section{SARAN}

Berdasarkan uraian pada kesimpulan tersebut perlu adanya saran yang berpotensi positif untuk pengembangan aplikasi dimasa yang akan datang. Saran yang perlu dipertimbangkan pada aplikasi ini adalah sebagai berikut :

1. Seiring dengan perkembangan teknologi, diharapkan juga memiliki SDM yang handal dalam penggunaan sistem.

2. Memperbaharui tampilan sistem yang lebih baik lagi sehingga para User tidak merasa bosan dalam menggunakan system ini.

3. Aplikasi sistem informasi manajemen data kepegawaian berbasis web, diharapkan kedepannya dapat menjadi acuan atau tolak ukur para admin dalam hal meningkatkan keefesienan waktu.

\section{UCAPAN TERIMA KASIH}

Penulis mengucapkan terimakasih kepada Perusahaan yang telah memberikan saya tempat riset untuk penelitian saya dan terimakasih juga kepada seluruh pegawai yang ada diperusahan tersebut sudah memberikan arahan yang baik dalam membimbing saya diperusahaan untuk menyelesaikan penelitian ini. 


\section{DAFTAR PUSTAKA}

[1] Achmad, H. A., Pudjiantoro, T. H., \& Renaldi, F. (2017). Sistem Informasi Manajemen Kepegawaian di Dinas Komunikasi dan Informatika Bandung Barat. Prosiding SNATIF, 405411.

[2] Abdurahman, M. (2018). Sistem Informasi data pegawai berbasis web pada kementerian Kelautan dan Perikanan Kota Ternate. Jurnal Ilmiah ILKOMINFO-Ilmu Komputer \& Informatika, 1(2).

[3] Sastrawan, M. S., Aditya Saputra, J., \& Elizabeth, T. Sistem Informasi Kepegawaian Pada Badan Pengelola Keuangan Dan Aset Daerah Provinsi Sumatera Selatan.

[4] Pratiwi, A. (2018). IMPLEMENTASI SISTEM INFORMASI MANAJEMEN KEPEGAWAIAN (SIMPEG) SEBAGAI DASAR PENGAMBILAN KEPUTUSAN BIDANG SUMBER DAYA MANUSIA (SDM) DI BKDIKLATDA KOTA SALATIGA. JMAN jurnal mahasiswa Administrasi negara, 2(2), 148-156.

[5] Maesaroh, S., \& Rohmayani, D. (2019). RANCANG BANGUN SISTEM INFORMASI KEPEGAWAIAN (SIMPEG) DENGAN SDLC METODE WATERFALL STUDI KASUS DI KANTOR BKPLD KABUPATEN TASIKMALAYA. Jurnal TEDC, 11(2), 197-202.

[6] Muslikhah, R. I. (2019). Dukungan Sistem Informasi Manajemen Kepegawaian terhadap Pengambilan Keputusan di Bkpp Kabupaten Sukoharjo. EFISIENSI-KAJIAN ILMU ADMINISTRASI, 16(2), 10-21.

[7] Sugiarto, S., Andrian, Y., Sianturi, E. V. H., \& Rosnelly, R. (2014). Perancangan Dan Implementasi Lampu Jalan Otomatis Dengan Menggunakan Solar Cell Berbasis ATMEGA 8535. Jurnal Eksplora Informatika, 4(1), 13-22.

[8] Safrizal, S., Tanti, L., \& Susianto, S. (2020). PENERAPAN APLIKASI SICERDAS BERBASIS WEB PADA SISWA RAUDHATUL ATHFAL (RA) NURUL HASANAH. Dharma Bhakti Ekuitas, 5(1), 464-471. 